\title{
Assessing the Impact of Changes to CG Codes on the Financial Performance of UAE Firms
}

\author{
Abdulfattah Mohamed G Khalifa H (Corresponding author) \\ Department of Management, Business School \\ Tripoli University, Tripoli, Libya \\ $\&$ \\ Victoria University Business School, Victoria University \\ Melbourne, Australia \\ E-mail: abdulfattah.khalifah@live.vu.edu.au \\ Riccardo Natoli \\ Victoria University Business School, Victoria University \\ Melbourne, Australia
}

Segu Zuhair

Department of Business, Management and Finance

Melbourne Polytechnic, Australia

Received: May 23, 2020

Accepted: July 3, 2020

Published: September 30, 2020

doi:10.5296/ijafr.v10i3.17081

URL: https://doi.org/10.5296/ijafr.v10i3.17081

\begin{abstract}
This study undertook a comparison of the changes to corporate governance (CG) practices, based on the UAE CG codes, for three different periods of time between 2006 to 2007, 2009 to 2010 and 2013 to 2014. An ordinary least squares model, along with analysis of variance testing, was employed to compare this. The study sample included 47 listed firms in the UAE. The changes made to the CG code during the study period affected the audit and board committee characteristics. The results show that the second CG code change had the most significant effect on board meetings, board members' education, board members' experience,
\end{abstract}


audit committee meetings and audit committee members' education impact on the financial performance of UAE listed firms. The potential policy implications arising from the study centre on ensuring greater firm compliance to meet the expectations of the regulatory body, as mandated in the CG code.

Keywords: CG codes, UAE, Board characteristics, Audit characteristics, Firm performance

\section{Introduction}

The rapid nature of the UAE's economic growth rate has made the UAE one of the most developed countries in the Middle East which, from a per capita perspective, is among the top 30 economies in the world (Trading Economics 2017). Despite this rapid growth and high levels of foreign investment, the regulatory and legal framework in the UAE has, as yet, failed to keep up with these changes. Thus, to address what has been recognised as lax governance practice laws, or poor corporate governance (CG), the UAE government in 2007 established the first CG code through Decision No. R/32 of 2007, which presented the primary regulatory framework for the Emirates Securities and Commodities Authority (ESCA).

Although this was a positive step towards tightening governance and transparency issues, Aljifri and Moustafa (2007) felt that the UAE first CG code could be improved to render it more suitable for the UAE business environment. Moreover, a report by the International Monetary Fund (IMF) (2007) stated that the first UAE CG code was weak and required improvement such as the incorporation of the OECD Principles of Corporate Governance. These criticisms, along with the global financial crisis (GFC), acted as a catalyst for the UAE to institute a second CG code in 2009 via the Ministerial Resolution No. 518 of 2009. Unlike the first CG code, the second CG code became mandatory for all listed companies, which were required to comply with the code by 30 April 2010 (Ministerial Resolution No. 518 of 2009).

The UAE became a better equipped to mitigate corruption following the advent of these CG codes. This was reflected in Transparency International's Corruption Perception Index, which saw the UAE move from the position of thirty-first cleanest country in terms of perceived corruption to twenty-third in 2015 (Andrew 2015). The shift to a more transparent and regulated financial environment via the implementation of CG codes also had direct effects on board and audit committee characteristics.

Consequently, the main objective of this study is to examine the influence of the changes to the CG codes on the financial performance of listed companies in the UAE via the prism of audit and board committee characteristics. To empirically examine this relationship the present study employed data on 47 listed companies on the Dubai Financial Market (DFM) and Abu Dhabi Securities Exchange (ADX). An ordinary least squares (OLS) regression model and analysis of variance (ANOVA) were then employed to analyse three-time periods to enable a comparative analysis of the effect of changes to the CG code and their effect on financial performance. The three-time periods are:

- Period 1: The period prior to the adoption of the first CG code: 2006 to 2007; 
- Period 2: The period two years after adoption of the first CG code: 2009 to 2010;

- Period 3: The period three years after adoption of the second CG code: 2013 to 2014.

Our empirical results show, the two amendments made to the corporate governance code during the study period affected the audit and board committee characteristics, as intended by these amendments. Of these amendments, the second amendment had the most significant effect on board meetings, board members' education, board members' experience, audit committee meetings and audit committee members' education.

Our study contributes to the CG literature by adding to the limited studies on CG in developing countries, and specifically in the UAE, has resulted in a significant gap between foundation theories and practical applicability. Specifically, the adoption of UAE CG codes and their effect on financial performance has not been addressed in the literature. This study will fill this knowledge gap by examining this relationship. The remainder of this paper is organised as follows. Section 2 reviews the UAE CG codes. Section 3 describes the research design. Section 4 presents results and discusses findings. Section 5 draws conclusions, implications and enters recommendations for further research.

\section{Literature Review}

\subsection{CG in the UAE}

The 1984 UAE Corporations Act incorporates articles that govern corporation management processes. This Act has formed rules (from Article 95 to 118) related to the board of directors' selection, composition, duties and management processes (Federal Law No. 8, 1984). For instance, Article 95 sets minimum and maximum number of directors while Articles 111 to 118 focus on the duties of a chairperson and board of directors (Federal Law No. 8, 1984). In addition, with respect to auditors, all corporations in the UAE are required to maintain proper financial records, including minimum accounting reports, financial statements, statement of profit and notes to these accounts. According to the Act, the annual audited accounts must be presented before shareholders at an annual general meeting (Federal Law No. 8, 1984). However, despite the 1984 Corporations Act, the laws surrounding CG behaviour of firms was still seen as lacking. Consequently, in 2006 the Hawkamah Institute for Corporate Governance was established to help strengthen CG practices in the UAE.

\subsection{UAE CG Codes}

The first CG code in the UAE was published in 2007through Decision No. R/32 of 2007, which was regulated by ESCA until 2010. This code identified the rules and procedures for making decisions in corporate relationships. It further clarified the shareholders' rights, composition of the board of directors and the audit committee, election of board of directors, board of directors' meetings and audit committee meetings. It also identified tasks and duties for the board of directors, audit committee and chairperson of the board of directors. The CG code provided for the company's articles of association to determine the size of the board and audit committee, and the remuneration of the directors of the board (ESCA 2007).

Some analysts, however, asserted that the provisions of the do not go far enough to address 
the prevailing CG issues (Ahmad 2010). Acknowledging this, the government issued a second code post-GFC to overcome the perceived gaps in the first code. Thus, in 2009, the Ministry of Economy of the UAE published Ministerial Resolution No. 518 of 2009, which is referred to as the second CG code. This code replaced the old code and enhanced CG rules and discipline standards for UAE public joint stock companies (PJSC) and institutions whose securities are listed on the market. In 2010, the CG code became mandatory for all listed companies, and compliance was required by 30 April 2010. Ministerial Reregulation No. 518 reflects the continuing efforts of the government to align the regulation of the investment markets in the UAE with those of the leading international financial markets (Ahmad 2010).

The second CG code is mandatory for all listed companies. The change from voluntary to mandatory meant that UAE listed firms were now compelled to adopt the CG codes. Hence, even if a CG code did not change in content from the first CG code to the second CG code (e.g., board of directors composition), the mandatory nature of the second CG code meant that it had the ability to affect the firm financial performance of UAE listed companies.

This second CG code established good standards of CG and was largely based on international standards. Both the Abu Dhabi Securities Exchange (ADX) and Dubai Financial Market (DFM) are licensed and regulated by the ESCA. The UAE government established the ESCA on 1 February 2000, pursuant to Federal Law No. 4 of 2000, under the leadership of the Minister of Economy and Commerce. Its function was to strength the legislative structure through issuing regulations and instructions that ensure the development of the organisational framework of UAE listed companies. It also regulates and develops the primary and secondary markets, monitors the market and promotes a safe and favourable environment for investors (ESCA 2000). According to Steven and Carla (2010), the two UAE $\mathrm{CG}$ codes have focused on making further improvements to $\mathrm{CG}$ rules.

The study period for the present research covers the first CG code (2007) and the second CG code (2010). Table 1 below provides a comparison of the first and second CG codes as they relate to board and audit committee characteristics chosen for the study, based on prior studies. They are: board size (Almatari et al. 2014b; Johl et al. 2015; Rouf 2011); board independent directors (Dabor et al. 2015; Khan and Awan 2012; Yasser et al. 2011); board meetings (Ntim \& Oseit 2011; Hsu \& Petchsakulwong 2010; Johl et al. 2015); board members' experience (Zhu \& Shen 2016; Johl et al. 2015; Hsu 2010); board members' education (Almatari et al. 2013; Vo \& Phan 2013; Hsu 2010); audit committee size (Hamdan et al. 2013; Aldamen et al. 2012; Ibrahim et al. 2009); audit committee independent members (Yasser et al. 2011; Almatari et al. 2014b; Ghabayen 2012); audit committee meetings (Hamdan et al. 2013; Alqatamin 2018; Almatari et al. 2014b); and audit committee members' education (Aldamen et al. 2012; Almatari et al. 2014a; Hamid \& Aziz 2012).

Table 1. Comparison of first and second codes of CG in the UAE

CG Characteristics

First CG Code (2007)

(Voluntary)
Second CG Code (2010) (Mandatory) 


\begin{tabular}{|c|c|c|}
\hline Board size & $\begin{array}{l}\text { The company's articles of } \\
\text { association can determine the } \\
\text { number on the board of directors. }\end{array}$ & $\begin{array}{l}\text { At least three members and a maximum } \\
\text { of } 15 \text { members. }\end{array}$ \\
\hline Board independent directors & $\begin{array}{l}\text { At least one-third of directors must } \\
\text { be independent directors. }\end{array}$ & $\begin{array}{l}\text { The board must comprise at least } \\
\text { one-third independent directors. }\end{array}$ \\
\hline Board meetings & $\begin{array}{l}\text { Meetings must be held at least } \\
\text { once every two months. }\end{array}$ & $\begin{array}{l}\text { The board meeting should be set once or } \\
\text { more every two months. }\end{array}$ \\
\hline Board members' experience & $\begin{array}{l}\text { Directors must have experience } \\
\text { and technical skills in the best } \\
\text { interests of the company. }\end{array}$ & $\begin{array}{l}\text { Board directors must be trained to } \\
\text { understand the company's policies, } \\
\text { organisational structure and business, as } \\
\text { well as their duties under the law. }\end{array}$ \\
\hline Board members' education & Not stated. & $\begin{array}{l}\text { Board members should have sufficient } \\
\text { qualifications, skills and experience to } \\
\text { conduct their duties. }\end{array}$ \\
\hline Audit committee size & Not stated. & $\begin{array}{l}\text { The audit committee should have at least } \\
\text { three members. }\end{array}$ \\
\hline $\begin{array}{l}\text { Audit committee } \\
\text { independent members }\end{array}$ & Not stated. & $\begin{array}{l}\text { The audit committee must comprise one } \\
\text { independent member. }\end{array}$ \\
\hline Audit committee meetings & $\begin{array}{l}\text { The audit committee should meet } \\
\text { once or more every three months } \\
\text { or whenever necessary. }\end{array}$ & $\begin{array}{l}\text { The audit committee should meet at } \\
\text { least once every three months. }\end{array}$ \\
\hline $\begin{array}{l}\text { Audit committee members' } \\
\text { education }\end{array}$ & $\begin{array}{l}\text { The audit committee should have } \\
\text { members with financial and } \\
\text { accounting backgrounds. }\end{array}$ & $\begin{array}{l}\text { The audit committee must have at least } \\
\text { one member with a financial } \\
\text { qualification or an expert in accounting } \\
\text { and financial affairs. }\end{array}$ \\
\hline
\end{tabular}

The primary contribution of the present research is a comparative analysis to examine the extent to which both CG codes have affected the financial performance of UAE listed companies

\section{Data and Research Methods}

\subsection{Data}

This study used secondary data obtained from different online sources: DFM, ADX, Mint Global, Orbis-Bureau van Dijk, DataStream, UAE listed firms' website and ESCA (see Appendix 1). Data related to firm financial performance were obtained from financial statements, such as balance sheets, income statements and cash flow statements provided in the respective annual reports.

The sample initially consisted of all UAE firms listed on the DFM and ADX as of July 2014 and the selection of companies was determined by the availability of data for each of the 


\section{MlMacrothink}

International Journal of Accounting and Financial Reporting

ISSN 2162-3082

2020, Vol. 10, No. 3

three time periods. In total, there were 127 listed companies at that time, with 59 listed companies on the DFM and 68 listed companies on the ADX for the overall study period 2006-2007; 2009-2010; 2013-2014. The years between these periods are deemed to be transition periods and are subsequently not included in the estimation models. The DFM and ADX markets were chosen because companies on these markets are more likely to attract and employ skilled and competent individuals on the boards of directors and audit committees. The listed companies selected in this study had to meet three criteria: (i) provide information about board and audit committee characteristics for the study period; (ii) provide financial performance information; and (iii) possess complete data for the study period. Based on these criteria, the number of firms was reduced to 61 because some listed firms did not have information available on the key explanatory variables identified in this study, while other firms did not have any information available via published accessible sites. Another 14 companies were omitted from the study sample because they contained outliers (Hair et al., 2010). As a result, the present study's final sample comprised 47 listed firms and 282 total observations.

The study estimated two equations: one for each of the financial performance variables, ROA and ROE. The estimated OLS regression is in the form:

$$
\begin{aligned}
\mathrm{FP}_{\mathrm{i}}=\alpha & +\beta_{1} \mathrm{BS}_{\mathrm{i}}+\beta_{2} \mathrm{BIND}+\beta_{3} \mathrm{BM}_{\mathrm{i}}+\beta_{4} \mathrm{BMED}_{\mathrm{i}}+\beta_{5} \mathrm{BMEX}_{\mathrm{i}}+\Sigma \beta_{6} \mathrm{ACS}_{\mathrm{i}}+\beta_{7} \mathrm{ACIND}_{\mathrm{i}} \\
& +\beta_{8} \mathrm{ACM}_{\mathrm{i}}+\beta_{9} \mathrm{ACED}_{\mathrm{i}}+\beta_{10} \mathrm{FA}_{\mathrm{i}}+\beta_{11} \mathrm{LEV}_{\mathrm{i}}+\beta_{12} \mathrm{FS}_{\mathrm{i}}+\mathrm{e}_{\mathrm{i}}
\end{aligned}
$$

where:

$\mathrm{BS}=$ board size

BIND $=$ board independent directors

$\mathrm{BM}=$ board meetings

BMED = board members' education

$\mathrm{BMEX}=$ board members' experience

ACS $=$ audit committee size

ACIND $=$ audit committee independent members

$\mathrm{ACM}=$ audit committee meetings

ACED = audit committee members' education

$\mathrm{FA}=$ firm age

$\mathrm{LEV}=$ leverage

$\mathrm{FS}=$ firm size

$\mathrm{FP}=$ financial performance, which includes ROA and ROE.

The estimation model controlled for firm age (FA), leverage (LEV) and firm size (FS) an 
approach widely used in CG studies. The models were estimated via OLS and via one-way ANOVA along with post-hoc tests.

\section{Results and Analysis}

\subsection{Descriptive Statistics}

Table 2 below provides the descriptive statistics on the study variables. The mean size of boards in the sample was 7.70, ranging from five to 15 members of which, on average, $71.24 \%$ were independent directors. This observation is consistent with the recommendations of the first and second UAE CG codes. On the average the companies had about six meetings in a year, ranging from a minimum of one meeting to a maximum of 16 meetings per year. In this study, the board members' education ranged from a minimum of $36 \%$ to a maximum of $100 \%$, with an average of $74.36 \%$ of board members holding a foreign degree from universities in developed countries. The mean board members' experience in the sample was 21 years, with a range from a minimum of seven years to a maximum of 39 years of experience for board members. The mean audit committee size in the sample comprised 3.32 committee members, ranging from a minimum of two members to a maximum of seven members.

The audit committee size was not stated in the first CG code in the UAE, while the second code stated that the audit committee should have at least three members. In addition, on average, $81.13 \%$ of audit committee members were independent, with a minimum of $20 \%$ and a maximum of $100 \%$. Further, the mean number of audit committee meetings was 4.70 , ranging from a minimum of two meetings to a maximum of 12 meetings per year. The audit committee members' education ranged from a minimum of $0 \%$ to a maximum of $100 \%$ of audit committee members holding a degree in a financial discipline. On average, $41.80 \%$ of members held a financial degree.

Table 2. Descriptive statistics of board and audit committee characteristics

\begin{tabular}{lccccc}
\hline \multicolumn{1}{c}{ Variable } & N & Abbr. & Minimum & Maximum & Mean \\
\hline Board size & 282 & BS & 5 & 15 & 7.70 \\
\hline Board independent directors & 282 & BIND & $33 \%$ & $100 \%$ & $71.24 \%$ \\
\hline Board meetings (per year) & 282 & BM & 1 & 16 & 6.15 \\
\hline Board members' education & 282 & BMED & $36 \%$ & $100 \%$ & $74.36 \%$ \\
\hline Board members' experience (years) & 282 & BMEX & 7 & 39 & 21.19 \\
\hline Audit committee size & 282 & ACS & 2 & 7 & 3.32 \\
\hline $\begin{array}{l}\text { Audit committee independent } \\
\text { members }\end{array}$ & 282 & ACIND & $20 \%$ & $100 \%$ & $81.13 \%$ \\
\hline Audit committee meetings (per year) & 282 & ACM & 2 & 12 & 4.70 \\
\hline Audit committee members' education & 282 & ACED & 0 & $100 \%$ & $41.80 \%$ \\
\hline
\end{tabular}




\section{Macrothink}

International Journal of Accounting and Financial Reporting

ISSN 2162-3082 2020, Vol. 10, No. 3

\subsection{Correlation Matrix}

Table 3 below presents the correlation coefficients for the variable set. Overall, the correlations are low with no indication of strong correlations as per the criteria of 0.80 (Grewal, Cote \& Baumgartner 2004; Shearer \& Clark 2016).

Table 3. Correlation matrix

\begin{tabular}{|c|c|c|c|c|c|c|c|c|c|c|c|c|c|}
\hline & BS & BIND & $\mathbf{B M}$ & BMED & BMEX & ACS & ACIND & $\mathbf{A C M}$ & ACED & ROA & ROE & $\mathbf{L V}$ & FA \\
\hline BS & 1 & & & & & & & & & & & & \\
\hline BIND & 0.096 & 1 & & & & & & & & & & & \\
\hline $\mathrm{BM}$ & 0.010 & $0.199^{* *}$ & 1 & & & & & & & & & & \\
\hline BMED & -0.017 & 0.041 & 0.010 & 1 & & & & & & & & & \\
\hline BMEX & $0.310^{* *}$ & -0.086 & 00.102 & $0.197^{* *}$ & 1 & & & & & & & & \\
\hline ACS & $0.418^{* *}$ & 0.061 & 0.062 & 0.061 & $0.172^{* *}$ & 1 & & & & & & & \\
\hline ACIND & 0.022 & $0.209^{* *}$ & 0.079 & 0.047 & 0.069 & 0.090 & 1 & & & & & & \\
\hline $\mathrm{ACM}$ & $0.318^{* *}$ & $0.181^{* *}$ & $0.350^{* *}$ & $0.173^{* *}$ & $0.265^{* *}$ & $0.252^{* *}$ & 0.114 & 1 & & & & & \\
\hline ACED & $-0.247 * *$ & 0.010 & 0.092 & -0.057 & 0.082 & $-0.207^{* *}$ & $0.204^{* *}$ & -0.050 & 1 & & & & \\
\hline ROA & 0.082 & -0.022 & 0.070 & -0.109 & $0.138^{*}$ & 0.037 & 0.057 & 0.040 & .008 & 1 & & & \\
\hline ROE & 0.019 & 0.070 & 0.010 & 0.043 & -0.076 & 0.033 & 0.032 & 0.103 & -.036 & $0.452^{* *}$ & 1 & & \\
\hline LEV & -0.058 & $0.398^{* * *}$ & $0.250^{* *}$ & 0.014 & 0.079 & $0.187^{* *}$ & 0.109 & 0.078 & -0.052 & -0.082 & 0.025 & 1 & \\
\hline FA & $0.168^{* * *}$ & 0.078 & 0.033 & 0.103 & 0.067 & 0.078 & -0.054 & -0.015 & $-.122^{*}$ & -0.052 & $0.001 *$ & 0.070 & 1 \\
\hline FS & 0.020 & 0.016 & $0.277^{* *}$ & 0.040 & 0.003 & $-0.176^{* *}$ & 0.060 & $0.301^{* *}$ & $.216^{* *}$ & -0.041 & 0.069 & $0.269^{* *}$ & -0.104 \\
\hline
\end{tabular}

** Correlation is significant at the 0.01 level (two-tailed).

* Correlation is significant at the 0.05 level (two-tailed).

\subsection{Collinearity}

Table 4 shows the results of the variance inflation factor (VIF) and tolerance for the independent and control variables in the model. A tolerance (1/VIF) value of less than 0.20 and a VIF value of greater than 10 indicates the presence of collinearity (Tabachnick \& Fidell 2007). The results suggest that all variables in the regression model have VIF factor scores below the benchmark of 10 and tolerance values greater than 0.20 , which indicates the absence of multicollinearity.

Table 4. Results for VIF and tolerance

\begin{tabular}{lcc}
\hline \multicolumn{1}{c}{ Variable } & VIF & Tolerance (1/VIF) \\
\hline Board size (BS) & 1.53 & 0.650 \\
\hline Board independent directors (BIND) & 1.52 & 0.655 \\
\hline Board meetings (BM) & 1.30 & 0.764 \\
\hline Board members' education (BMED) & 1.10 & 0.902 \\
\hline Board members' experience (BMEX) & 1.31 & 0.760 \\
\hline
\end{tabular}




\begin{tabular}{lll}
\hline Audit committee size (ACS) & 1.44 & 0.693 \\
\hline Audit committee independent members (ACIND) & 1.25 & 0.795 \\
\hline Audit committee meeting (ACM) & 1.65 & 0.603 \\
\hline Audit committee members' education (ACED) & 1.24 & 0.802 \\
\hline Firm age (FA) & 1.08 & 0.662 \\
\hline Leverage (LEV) & 1.51 & 0.921 \\
\hline Firm size (FS) & 1.48 & 0.673 \\
\hline
\end{tabular}

\subsection{Effects of Return on Assets Model}

The results of the ROA model are given in Table 5 below. The estimates for the three sub-periods models are significant ( $\mathrm{p}$-value $<0.001$ ). The $\mathrm{R}^{2}$ indicates that the predictors are able to explain $47.8 \%$ of variation in firm financial performance for Period 1, $49.5 \%$ for Period 2 and $49.9 \%$ for Period 3. The results demonstrate that the OLS model fits the study data for the three sub-periods.

Table 5. ROA Models using OLS for three sub-periods-Period 1 (2006-2007), Period 2 (2009-2010) and Period 3 (2013-2014)

\begin{tabular}{|c|c|c|c|c|c|c|}
\hline \multirow[t]{2}{*}{ Model } & \multicolumn{2}{|c|}{$\begin{array}{c}\text { Period 1 } \\
(2006-2007)\end{array}$} & \multicolumn{2}{|c|}{$\begin{array}{c}\text { Period 2 } \\
(2009-2010)\end{array}$} & \multicolumn{2}{|c|}{$\begin{array}{c}\text { Period 3 } \\
(2013-2014)\end{array}$} \\
\hline & Estimate & p-value & Estimate & p-value & Estimate & p-value \\
\hline (Constant) & -2.970 & 0.104 & 0.986 & 0.452 & 1.460 & 0.328 \\
\hline BS & 0.100 & 0.248 & 0.163 & 0.009 & -0.059 & 0.238 \\
\hline BIND & 0.003 & 0.767 & 0.006 & 0.354 & 0.001 & 0.890 \\
\hline BM & 0.233 & 0.113 & 0.266 & 0.007 & 0.021 & 0.750 \\
\hline BMED & 0.027 & 0.005 & -0.002 & 0.732 & -0.005 & 0.522 \\
\hline BMEX & 0.023 & 0.525 & -0.055 & 0.027 & -0.024 & 0.270 \\
\hline $\mathrm{ACS}$ & 0.067 & 0.777 & -0.007 & 0.970 & 0.251 & 0.247 \\
\hline ACIND & 0.035 & $<0.001$ & 0.025 & $<0.001$ & 0.042 & $<0.001$ \\
\hline $\mathrm{ACM}$ & -0.001 & 0.997 & 0.055 & 0.530 & 0.176 & 0.005 \\
\hline ACED & 0.016 & 0.015 & 0.005 & 0.371 & 0.005 & 0.153 \\
\hline LEV & 0.001 & 0.940 & -0.001 & 0.745 & 0.004 & 0.447 \\
\hline FA & 0.008 & 0.579 & 0.030 & 0.005 & 0.003 & 0.788 \\
\hline FS & 0.030 & 0.884 & -0.313 & 0.040 & -0.030 & 0.829 \\
\hline$R$-squared & 0.478 & & 0.495 & & 0.499 & \\
\hline$F$-statistic & 5.720 & & 6.440 & & 6.720 & \\
\hline$p$-value & $<0.001$ & & $<0.001$ & & $<0.001$ & \\
\hline
\end{tabular}

Note $: \mathbf{B S}=$ board size, BIND = board independent directors, $\mathbf{B M}=$ board meetings, BMED = board members' education, BMEX = board members' experience, ACS = audit committee size, $\mathbf{A C I N D}=$ audit committee independent members, $\mathbf{A C M}=$ audit committee meeting, ACED = audit committee members' education, LEV = leverage, $\mathbf{F A}=$ firm age, $\mathbf{F S}=$ firm 


\section{Macrothink}

International Journal of Accounting and Financial Reporting

ISSN 2162-3082

2020, Vol. 10, No. 3

size.

The results for board characteristics show no relationship between ROA and board size in Periods 1 and 3; however, in Period 2 the relationship is significant and positive. The association between ROA and both board independent directors and board meetings is positive for all three periods; however, the association between ROA and board meetings is significant only for e Period 2. The relationship between ROA and board members' education in Period 1 is significant and positive, while Periods 2 and 3 show no significant relationship. Finally, there is no significant association between ROA and board members' experience for Periods 1 and 3, while it is significant and negative for Period 2.

The results for the audit committee characteristics and ROA demonstrated no significant relationship between ROA and audit committee size. With respect to audit committee independent members it was demonstrated to have a significant and positive effect on ROA for all three periods. The association between ROA and audit committee meetings was also significant and positive but only for Period 3, while audit committee members' education displayed a significant and positive effect on ROA for Period 1 only.

\subsection{Effects of Return on Equity Model}

The results of the ROE model are given in Table 6 below. The estimates for the three sub-periods are significant ( $\mathrm{p}$-value $<0.001$ ). The $\mathrm{R}^{2}$ indicates that the predictors are able to explain 50.2\% of variation in firm financial performance for Period 1, 41.7\% for Period 2 and $48.9 \%$ for Period 3 . The results demonstrate that the OLS model fits the study data for three sub-periods.

Table 6. ROE Models using OLS for three sub-periods-Period 1(2006-2007), Period 2 (2009-2010) and Period 3 (2013-2014)

\begin{tabular}{lcccccc}
\hline \multirow{2}{*}{ Model } & \multicolumn{2}{c}{ Period 1 } & \multicolumn{2}{c}{ Period 2 } & \multicolumn{2}{c}{ Period 3 } \\
& \multicolumn{2}{c}{$(\mathbf{2 0 0 6 - 2 0 0 7 )}$} & $\mathbf{( 2 0 0 9 - 2 0 1 0 )}$ & (2013-2014) \\
\cline { 2 - 6 } & Estimate & p-value & Estimate & p-value & Estimate & p-value \\
\hline Constant) & 0.841 & 0.688 & 1.130 & 0.499 & 1.590 & 0.390 \\
\hline BS & 0.092 & 0.358 & 0.180 & 0.024 & 0.046 & 0.457 \\
\hline BIND & -0.035 & 0.001 & -0.005 & 0.505 & -0.013 & 0.060 \\
\hline BM & 0.340 & 0.046 & 0.380 & 0.003 & 0.116 & 0.166 \\
\hline BMED & 0.007 & 0.504 & -0.012 & 0.181 & -0.003 & 0.730 \\
\hline BMEX & -0.035 & 0.409 & -0.107 & 0.001 & -0.029 & 0.270 \\
\hline ACS & -0.523 & 0.058 & -0.038 & 0.874 & 0.042 & 0.874 \\
\hline ACIND & 0.010 & 0.239 & 0.001 & 0.988 & 0.015 & 0.049 \\
\hline ACM & 0.344 & 0.068 & 0.272 & 0.016 & 0.407 & $<0.001$ \\
\hline ACED & 0.039 & $<0.001$ & 0.030 & $<0.001$ & 0.020 & $<0.001$ \\
\hline LEV & 0.011 & 0.184 & 0.003 & 0.569 & 0.004 & 0.517 \\
\hline FA & -0.007 & 0.648 & 0.025 & 0.073 & -0.010 & 0.425 \\
\hline
\end{tabular}




\begin{tabular}{|c|c|c|c|c|c|c|}
\hline FS & 0.210 & 0.370 & -0.282 & 0.147 & 0.157 & 0.365 \\
\hline$R$-squared & 0.502 & & 0.417 & & 0.489 & \\
\hline$F$-test (ANOVA) & 6.300 & & 4.710 & & 6.460 & \\
\hline$p$-value $(F$-test $)$ & $<0.001$ & & $<0.001$ & & $<0.001$ & \\
\hline
\end{tabular}

Note: Refer to note in Table 5 for full variable names.

The results for board characteristics and ROE show no significant relationship between ROE and board size for Periods 1 and 3; however, Period 2 is significant and positive. The association between ROE and board independent directors is negative for all periods, with Periods 1 and 3 being significant. For board meetings, there is a significant and positive relationship for Periods 1 and 2, while board members' education displays no significant relationships for all three periods. The association between ROE and board members' experience is negative for all periods, but is only significant for Period 2.

In regard to the relationship between audit committee characteristics and ROE, the result shows a significant negative relationship between ROE and audit committee size for Period 1, while the association between ROE and audit committee independent members is significant and positive for Period 3. For the variables audit committee meeting and audit committee members' education, there is a significant and positive effect on ROE for all three periods.

In this study, comparisons of the mean values of board and audit committee characteristics and the financial performance of the UAE listed companies are tested to determine any significant changes in CG practices during the three selected periods. Specifically, one-way ANOVA and multiple comparison analysis (Tukey's HSD) are conducted to examine the difference between the groups by classifying the periods into three groups in accordance with the changes in UAE CG codes. A one-way ANOVA is employed to compare the difference between the means of the dependent and independent variables in the three periods. Table 7 shows the results.

Table 7. ANOVA Test

\begin{tabular}{llcccc}
\hline & & Sum of Squares & Mean Square & F & p-value \\
\hline BS & Between groups & 6.05 & 3.025 & 0.650 & 0.523 \\
\hline BIND & Between groups & 33.792 & 16.896 & 0.046 & 0.955 \\
\hline BM & Between groups & 50.764 & 25.382 & 14.21 & $<0.001$ \\
\hline BMED & Between groups & $7,530.52$ & 3765.2 & 18.10 & $<0.001$ \\
\hline BMEX & Between groups & $1,281.15$ & 640.57 & 29.59 & $<0.001$ \\
\hline ACS & Between groups & 0.135 & 0.067 & 0.185 & 0.831 \\
\hline ACIND & Between groups & 87.633 & 43.817 & 0.110 & 0.896 \\
\hline ACM & Between groups & 44.053 & 22.026 & 10.25 & $<0.001$ \\
\hline ACED & Between groups & $6,372.04$ & 3186.0 & 5.434 & 0.005 \\
\hline ROA & Between groups & 11.428 & 5.714 & 3.459 & 0.033 \\
\hline ROE & Between groups & 225.464 & 112.73 & 48.69 & $<0.001$ \\
\hline
\end{tabular}


Note: Refer to note in Table 5 for full variable names.

Table 8. Multiple comparisons (Tukey's HSD)

\begin{tabular}{|c|c|c|c|c|c|}
\hline & Period (i) & Period (j) & $\begin{array}{c}\text { Mean } \\
\text { Difference (i-j) }\end{array}$ & $\begin{array}{c}\text { Std } \\
\text { Error }\end{array}$ & p-value \\
\hline \multirow[t]{3}{*}{ BS } & Period 2 & Period 1 & 0.043 & 0.315 & 0.990 \\
\hline & \multirow[t]{2}{*}{ Period 3} & Period 1 & 0.330 & 0.315 & 0.547 \\
\hline & & Period 2 & 0.287 & 0.315 & 0.633 \\
\hline \multirow[t]{3}{*}{ BIND } & Period 2 & Period 1 & -0.058 & 2.785 & 0.999 \\
\hline & \multirow[t]{2}{*}{ Period 3} & Period 1 & 0.703 & 2.785 & 0.966 \\
\hline & & Period 2 & 0.762 & 2.785 & 0.960 \\
\hline \multirow[t]{3}{*}{$\mathrm{BM}$} & Period 2 & Period 1 & 0.313 & 0.198 & 0.256 \\
\hline & \multirow[t]{2}{*}{ Period 3} & Period 1 & $1.026^{* *}$ & 0.198 & $<0.001$ \\
\hline & & Period 2 & $0.713^{* *}$ & 0.195 & $<0.001$ \\
\hline \multirow[t]{3}{*}{ BMED } & Period 2 & Period 1 & 4.536 & 2.103 & 0.081 \\
\hline & \multirow[t]{2}{*}{ Period 3} & Period 1 & $12.500^{* *}$ & 2.103 & $<0.001$ \\
\hline & & Period 2 & $7.965^{* *}$ & 2.103 & $<0.001$ \\
\hline \multirow[t]{3}{*}{ BMEX } & Period 2 & Period 1 & $2.546^{* *}$ & 0.679 & $<0.001$ \\
\hline & \multirow[t]{2}{*}{ Period 3} & Period 1 & $5.220^{* *}$ & 0.679 & $<0.001$ \\
\hline & & Period 2 & $2.675^{* *}$ & 0.679 & $<0.001$ \\
\hline \multirow[t]{3}{*}{ ACS } & Period 2 & Period 1 & 0.032 & 0.088 & 0.930 \\
\hline & \multirow[t]{2}{*}{ Period 3} & Period 1 & 0.053 & 0.088 & 0.818 \\
\hline & & Period 2 & 0.021 & 0.088 & 0.968 \\
\hline \multirow[t]{3}{*}{ ACIND } & Period 2 & Period 1 & -0.218 & 2.907 & 0.997 \\
\hline & \multirow[t]{2}{*}{ Period 3} & Period 1 & -1.276 & 2.907 & 0.899 \\
\hline & & Period 2 & -1.057 & 2.907 & 0.930 \\
\hline \multirow[t]{3}{*}{$\mathrm{ACM}$} & Period 2 & Period 1 & 0.493 & 0.215 & 0.058 \\
\hline & \multirow[t]{2}{*}{ Period 3} & Period 1 & $0.968^{* *}$ & 0.214 & $<0.001$ \\
\hline & & Period 2 & 0.475 & 0.215 & 0.071 \\
\hline \multirow[t]{3}{*}{ ACED } & Period 2 & Period 1 & -0.217 & 3.531 & 0.998 \\
\hline & \multirow[t]{2}{*}{ Period 3} & Period 1 & $9.973^{*}$ & 3.531 & 0.014 \\
\hline & & Period 2 & $10.190^{*}$ & 3.531 & 0.012 \\
\hline \multirow[t]{3}{*}{ ROA } & Period 2 & Period 1 & -0.247 & 0.190 & 0.397 \\
\hline & \multirow[t]{2}{*}{ Period 3} & Period 1 & 0.245 & 0.190 & 0.404 \\
\hline & & Period 2 & $0.493^{*}$ & 0.187 & 0.024 \\
\hline \multirow[t]{3}{*}{ ROE } & Period 2 & Period 1 & -0.034 & 0.225 & 0.987 \\
\hline & \multirow[t]{2}{*}{ Period 3} & Period 1 & $1.889^{* *}$ & 0.225 & $<0.001$ \\
\hline & & Period 2 & $1.923^{* *}$ & 0.221 & $<0.001$ \\
\hline
\end{tabular}

Note: Refer to note in Table 5 for full variable names; ** Mean difference is significant at the 0.01 level; * Mean difference is significant at the 0.05 level. 
There were significant differences between the mean values of the following independent variables: board meetings, board members' education, board members' experience, audit committee meetings and audit committee members' education. In addition, all three firm financial performance measures showed significant differences within their respective means over the three identified periods. Thus, from an overall perspective, changes to the CG codes seem to have affected the CG characteristics and financial performance of UAE listed firms. However, as stated previously, the ANOVA test does not indicate which pairs of means are significantly different. To identify this, a post hoc Tukey test is performed and the results are given in Table 8.

From an overall perspective, the post hoc tests on the ANOVA indicated that the adoption of CG codes did result in a significant positive change to board meetings, board members' education, board members' experience, audit committee meetings and audit committee members' education, while no significant changes were observed in board size, board independent directors, audit committee size and audit committee independent members.

With respect to the statistically significant variables, board meetings demonstrated a significant difference of means for Period 3, which encompasses the second CG code. The recommendations in the first and second CG codes are fairly similar, as both expect meetings to be held at least once every two months. Thus, the results suggest that firms in the sample data were not adhering to the first CG code, and that the move to make the second CG code mandatory had the effect of causing significantly more firms to follow the stipulation.

There are statistically significant differences in the level of board members' education, which imply that there was a significant difference in the number of directors who studied in foreign developed countries between the sub-periods. Hence, the change to the governance rules caused significant changes to board members' education within the listed companies.

The Tukey post hoc test results for board members' experience show statistically significant differences between means for all sub-periods. The study results suggest that the second CG code emphasis on improving experience by having board members undertake training to better understand company policies, structure and duties under law has resulted in a positive effect among UAE listed firms.

With respect to audit committee meetings, the Tukey test showed statistically significant differences over the selected periods was significant. Hence, although the wording of this specific CG code did not change much, the fact that the first CG code was voluntary, while the second CG code was mandatory, suggests that this could be the reason for the significant change that resulted in increased audit committee meetings among the UAE listed companies.

A Tukey post hoc test revealed statistically significant differences between the audit committee members' education periods due to the onset of the second CG code. Specifically, it resulted in a significant difference in the ratio of number of audit committee members holding a degree in a financial discipline to the total members in the committee over the selected periods. 


\section{MIMacrothink}

International Journal of Accounting and Financial Reporting

ISSN 2162-3082

2020, Vol. 10, No. 3

Firm financial performance comprises two measures: ROA and ROE. The Tukey post hoc test revealed differences in the financial parameters across the selected periods. The results showed statistically significant findings for ROA and ROE Q after the adoption of the second CG code. Specifically, there was a significant increase in ROA in Period 3 compared with Period 2, while ROE experienced a significant increase in Period 3 compared with Periods 1 and 2. The significant results for both firm financial performance measures suggests that changes to the second $\mathrm{CG}$ code had a positive effect on the financial performance of UAE listed companies.

To further understand this impact, a comparative analyses was employed to investigate the changes occurring in the relationship between board and audit committee characteristics and firm financial performance between the periods of 2006 to 2007, 2009 to 2010 and 2013 to 2014 as measured by ROA and ROE. The results are in Table 9 below.

The results show that changes to the UAE CG codes had a statistically significant impact on the relationship between board size and firm financial performance for both ROA and ROE. Specifically, ROA changed to significant after the first CG code adoption (Period 2) and to negative and insignificant after the adoption of the second CG code (Period 3). ROE changed to significant after the first CG code (Period 2) and then to insignificant after the second CG code (Period 3). This suggests that there was no significant effect on board size by changing the UAE CG codes from voluntary to mandatory.

Table 9. Comparative analyses three sub-periods_-Period 1(2006-2007), Period 2 (20092010) and Period 3 (2013-2014)

\begin{tabular}{lcc}
\hline \multicolumn{1}{c}{ Board and Audit Committee Variables } & ROA & ROE \\
\hline BS Period 1 & Pos, Insig & Pos, Insig \\
\hline BS Period 2 & Pos, Sig & Pos, Sig \\
\hline BS Period 3 & Neg, Insig & Pos, Insig \\
\hline BIND Period 1 & Pos, Insig & Neg, Sig \\
\hline BIND Period 2 & Pos, Insig & Neg, Insig \\
\hline BIND Period 3 & Pos, Insig & Neg, Sig \\
\hline BM Period 1 & Pos, Insig & Pos, Sig \\
\hline BM Period 2 & Pos, Sig & Pos, Sig \\
\hline BM Period 3 & Pos, Insig & Pos, Insig \\
\hline BMED Period 1 & Pos, Sig & Pos, Insig \\
\hline BMED Period 2 & Neg, Insig & Neg, Insig \\
\hline BMED Period 3 & Neg, Insig & Neg, Insig \\
\hline BMEX Period 1 & Pos, Insig & Neg, Insig \\
\hline BMEX Period 2 & Neg, Sig & Neg, Sig \\
\hline BMEX Period 3 & Neg, Sig & Neg, Insig \\
\hline
\end{tabular}




\begin{tabular}{lcc}
\hline ACS Period 1 & Pos, Insig & Neg, Sig \\
\hline ACS Period 2 & Neg, Insig & Neg, Insig \\
\hline ACS Period 3 & Pos, Insig & Neg, Insig \\
\hline ACIND Period 1 & Pos, Sig & Pos, Insig \\
\hline ACIND Period 2 & Pos, Sig & Pos, Insig \\
\hline ACIND Period 3 & Pos, Sig & Pos, Sig \\
\hline ACM Period 1 & Neg, Insig & Pos, Sig \\
\hline ACM Period 2 & Pos, Insig & Pos, Sig \\
\hline ACM Period 3 & Pos, Sig & Pos, Sig \\
\hline ACED Period 1 & Pos, Sig & Pos, Sig \\
\hline ACED Period 2 & Pos, Insig & Pos, Sig \\
\hline ACED Period 3 & Pos, Insig & Pos, Sig \\
\hline
\end{tabular}

Note: Refer to note in Table 5 for full variable names; Pos $=$ positive, $\mathbf{N e g}=$ negative, $\mathbf{S i g}=$ significant, Insig = insignificant, Period $1=2006-2007$, Period $2=2009-2010$, Period $3=$ 2013-2014.

With respect to board meetings, the change in UAE CG codes had a positive impact on firm financial performance for both models. A possible reason for this could be the number of the meetings prescribed under the new codes enabling the board to be more effective in providing timely governance directions to the management and reduce the unproductive activities. As Table 1 showed, both the first and second UAE CG codes stated that board meetings should be set once or more every two months; however, there was no maximum limit recommended by the codes. As Fich and Shivdasani (2006) and Lipton and Lorsch (1992) demonstrated, frequent meetings can lead to resources being channelled towards less productive activities and thereby affecting firm financial performance.

For board members' education and firm financial performance, the relationship changed from significant and positive in the first period (pre CG code 1) to insignificant and negative in the second and third periods for ROA and remained insignificant throughout for ROE. Although board members' education is an important resource for the UAE to improve its financial performance - and is typically proxied via education qualification to equate to managerial quality - other factors might also need to be considered, such as managerial skills, networks and other skills obtained outside of an educational qualification. This could act as a basis for future studies.

The result for the relationship between board members' experience and firm financial performance for ROA saw firm financial performance became significant and negative for both periods 2 and 3 as opposed to positive and insignificant in period 1. While for ROE, all three periods had a negative direction but it was significant for period 2 . The Tukey multiple comparisons test indicated that board members' experience increased after adopting the first and second UAE CG codes. 
In light of the results from the present research, the UAE CG code should specify the required competencies of directors. According to Kikhia (2014), board members who have financial expertise enhance the quality of oversight by the board. This enhanced oversight may substitute increased auditor effort and reduce the auditor's assessment of controlled risk, thereby resulting in improved firm financial performance.

The result of the OLS test showed that the CG codes appear to have affected the relationship between audit committee meeting and firm financial performance as measured by ROA but remain unchanged for ROE. Although the CG code suggested that the audit committee should meet at least once every three months, some firms did not strictly comply with this law, which could negatively affect the firm financial performance (see Table 1). This is a possible reason for the changes in the relationship between audit committee meetings and firm financial performance.

With respect to the relationship between audit committee members' education and firm financial performance, the result shows that the changes to the UAE CG rule had an insignificant effect on the relationship between audit committee members' education and firm financial performance for the ROA model (e.g., Periods 2 and 3). The relationship with ROE remained unchanged for all three periods. The Tukey test revealed a significant difference period 3 which indicated a greater number of audit committee members holding a degree in a financial discipline to the total members in the committee, compared with the other two periods. Hence, the changes to the governance rules in 2010 caused significant changes to committee members' education within the listed UAE companies. Having audit committee members with financial qualifications is very important for UAE listed companies. However, this study found that audit committee members can come from a wide variety of backgrounds and may not have sufficient financial or accounting knowledge, which could negatively affect firm financial performance.

Although some variables remained unchanged during the changes to the UAE CG codes, the majority of them did change, which affected firm financial performance. This study reached the conclusion that a higher level of compliance with CG codes will improve performance, as measured by various instruments. It is also notable that effective boards and audit committees can compensate for shortfalls in compliance, at least to some extent.

\section{Conclusions and Implications}

The study sought to identify the changes in the relationship between board and audit committee characteristics and firm financial performance due to changes in the CG codes. According to the results of the OLS regression, the changes to the UAE CG codes affected the relationship between board and audit committee characteristics and firm financial performance. In addition to the OLS regression, a one-way ANOVA with Tukey post hoc tests provided further specific information regarding how the changes to each variable, based on changes to the CG codes, affected the relationship between board and audit committee characteristics and firm financial performance.

Specifically, the ANOVA test showed that, from an overall perspective, changes to the CG 
codes resulted in a positive and significant increase on the financial performance of listed companies in the UAE as measured by ROA and ROE. Post hoc tests on the ANOVA indicated that the adoption of CG codes did result in a significant positive change to board meetings, board members' education, board members' experience, audit committee meetings and audit committee members' education, while board size, board composition, audit committee size and audit committee composition did not change.

This study tested the effect of the first and second CG codes on financial performance of UAE listed companies. Consequently, the present research provided new insights into the impact that the changes to CG codes had on the financial performance of UAE listed firms.

Some implications from the results suggest that UAE listed firms need to improve the quality of CG reports to more accurately reflect the firm's relationship and to ensure that they comply with the new rules arising from the UAE CG codes. Further, deliberate efforts should be invested to establish a follow-up and compliance team to ensure that all firms not only comply, but also meet the expectations of the regulatory body, as mandated in the CG code.

With respect to further areas for research, in 2016, the UAE introduced a third set of CG codes. Thus, future studies could undertake a comparative study comparing 2016 to 2017 with previous years to identify any improvements from the implementation. Further studies could also expand the notion of CG beyond board and audit committee characteristics by exploring the effects of various other committees, such as remuneration and nomination committees.

\section{References}

Ahmad, A. (2010). Spotlight on corporate governance. International Financial Law Review, 29(6), 105-106.

Aldamen, H., Duncan, K., Kelly, S., McNamara, R., \& Nagel, S. (2012). Audit committee characteristics and firm performance during the global financial crisis. Accounting \& Finance, 52(4), 971-1000.

Aljifri, K., \& Moustafa, M. (2007). The impact of corporate governance mechanisms on the performance of UAE firms: An empirical analysis. Journal of Economic and Administrative Sciences, 23(2), 71-93.

Almatari, E., Alswidi, A., \& Fadzil, F. (2013). The effect of the internal audit and firm performance: A proposed research framework. International Review of Management and Marketing, 4(1), 34-41.

Almatari, E., Alswidi, A., \& Fadzil, F. (2014a). The effect on the relationship between board of directors characteristics on firm performance in Oman: Empirical study. Middle-East Journal of Scientific Research, 21(3), 556-574.

Almatari, E., Alswidi, A., \& Fadzil, F. (2014b). The effect of board of directors characteristics, audit committee characteristics and executive committee characteristics on firm performance in Oman: An empirical study. Asian Social Science, 10(11), 149-171.

Alqatamin, R. M. (2018). Audit committee effectiveness and company performance: 


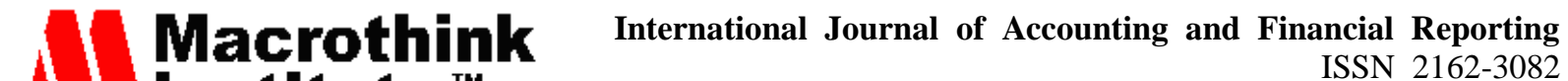 2020, Vol. 10, No. 3}

Evidence from Jordan. Accounting and Finance Research, 7(2), 48-60.

Andrew, H. (2015). UAE says no to corruption. Retrieved 12 September 2016, from https://www.lexology.com/library/detail.aspx?g=9764a038-309a-45ee-9411-e59aa78e3fae

Dabor, A. O., Isiavwe, D. T., Ajagbe, M. A., \& Oke, A. O. (2015). Impact of corporate governance on firms' performance. International Journal of Economics, Commerce and Management, 3(6), 634-653.

Emirates Securities \& Commodities Authority (ESCA). (2000). The Authority Board Resolution No. (3) of 2000 on the Regulations of Disclosure and Transparency and the amendments. United Arab Emirates.

Emirates Securities \& Commodities Authority (ESCA). (2007). Corporate governance code through decision No. R/32 of 2007. Corporate Governance Code, United Arab Emirates.

Federal Law No. (8). (1984). Commercial companies, and the laws in amendment. United Arab Emirates.

Fich, E. M., \& Shivdasani, A. (2006). Are busy boards effective monitors?. The Journal of Finance, 61(2), 689-724.

Ghabayen, M. A. (2012). Board characteristics and firm performance: Case of Saudi Arabia. International Journal of Accounting and Financial Reporting, 2(2), 168-200.

Grewal, R., Cote, J. A., \& Baumgartner, H. (2004). Multicollinearity and measurement error in structural equation models: Implications for theory testing. Marketing Science, 23(4), 519-529.

Hair, J., Black, W., Babin, B., \& Anderson, R. (2010). Multivariate data analysis (7th ed.). Upper Saddle River, Pearson Education International, New Jersey.

Hamdan, A. M., Sarea, A. M., \& Reyad, S. M. R. (2013). The impact of audit committee characteristics on the performance: Evidence from Jordan. International Management Review, $9(1), 32-41$.

Hamid, A., \& Aziz, R. (2012). Impact of the amendments of Malaysian code of corporate governance (2007) on governance of GLCS and performance. International Journal of Social, Behavioral, Educational, Economic, Business and Industrial Engineering, 6(11), 3181-3186.

Hsu, H-E. (2010). The relationship between board characteristics and financial performance: an empirical study of United States initial public offerings. International Journal of Management, 27(2), 332-341.

Hsu, W., \& Petchsakulwong, P. (2010). The impact of corporate governance on the efficiency performance of the Thai non-life insurance Industry. The Geneva Papers on Risk and Insurance-Issues and Practice, 25(1), 28-49.

Ibrahim, D. N., Raman, K. J., \& Saidin, F. B. S. (2009). Audit committee characteristics and quality of unaudited financial accounts. Singapore Management Review, 31(2), 19-33.

International Monetary Fund. (2007). United Arab Emirates: Financial System Stability 


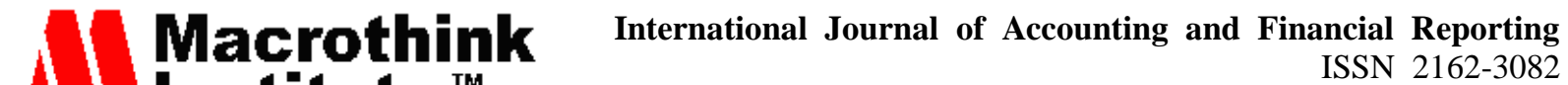 2020, Vol. 10, No. 3}

Assessment. Country Report No.07/357, Washington, D.C.

Johl, S. K., Kaur, S., \& Cooper, B. J. (2015). Board characteristics and firm performance: evidence from Malaysian public listed firms. Journal of Economics, Business and Management, 3(2), 339-343.

Khan, A., \& Awan, S. H. (2012). Effect of board composition on firm's performance: a case of Pakistani listed companies. Interdisciplinary Journal of Contemporary Research in Business, 3(10), 853-863.

Kikhia, H. Y. (2014). Board characteristics, audit committee characteristics, and audit fees: Evidence from Jordan. International Business Research, 7(12), 98-110.

Lipton, M., \& Lorsch, J. W. (1992). A modest proposal for improved corporate governance. Business Lawyer, 48(1), 59-77.

Ntim, C. G., \& Oseit, K. A. (2011). The impact of corporate board meetings on corporate performance in South Africa. African Review of Economics and Finance, 2(2), 83-103.

Rouf, M. (2011). The relationship between corporate governance and value of the firm in developing countries: Evidence from Bangladesh. The International Journal of Applied Economics and Finance, 5(3), 237-244.

Shearer, R., \& Clark, T. (2016). Are we drawing the correct conclusions? Regression analysis in the nonprofit literature. Canadian Journal of Nonprofit and Social Economy Research, $7(1), 22-28$.

Steven, B., \& Carla, S. (2010). United Arab Emirates: Changes in Corporate Governance Legislation Ministerial Resolution No. 518 of 2009. Retrieved 25 May 2016, from http://www.mondaq.com/x/96232/corporate+governance/changes+in+corporate+go\%20verna nce+legislation+ministerial+resolution+no+518+of +2009

Tabachnick, B., \& Fidell, L. (2007). Multivariate analysis of variance and covariance. Using Multivariate Statistics, 3(4), 402-407.

Trading Economics. (2017). Trading, economics-UAE GDP. Retrieved 19 August 2017, from http://www.tradingeconomics.com/united-arab-emirates/gdp

Vo, D., \& Phan, T. (2013). Corporate governance and firm performance: Empirical evidence from Vietnam. Journal of Economic Development, 6(2), 62-78.

Yasser, Q. R., Entebang, H. A., \& Mansor, S. A. (2011). Corporate governance and firm performance in Pakistan: the case of Karachi Stock Exchange (KSE)-30. Journal of Economics and International Finance, 3(8), 482-491.

Zhu, D. H., \& Shen, W. (2016). Why do some outside successions fare better than others? The role of outside CEOs' prior experience with board diversity. Strategic Management Journal, 37(13), 1-28. 


\section{Macrothink \\ International Journal of Accounting and Financial Reporting \\ ISSN 2162-3082 \\ 2020, Vol. 10, No. 3}

\section{Appendix 1. Study Variables and Their Measures}

\begin{tabular}{|c|c|c|c|c|}
\hline No & & Variables & Measures & Sources \\
\hline \multirow[t]{5}{*}{1} & \multirow{5}{*}{$\begin{array}{l}\text { Board } \\
\text { characteristics } \\
\text { (BC) }\end{array}$} & Board size (BS) & The number of members in the board & $\begin{array}{l}\text { DFM, ADX, ESCA and firm annual and } \\
\text { CG reports }\end{array}$ \\
\hline & & $\begin{array}{l}\text { Board independent directors } \\
\text { (BIND) }\end{array}$ & $\begin{array}{l}\text { The ratio of independent members to total } \\
\text { members in the board }\end{array}$ & $\begin{array}{l}\text { DFM, ADX, ESCA and firm annual and } \\
\text { CG reports }\end{array}$ \\
\hline & & Board meetings (BM) & The number of board meetings held per year & $\begin{array}{l}\text { DFM, ADX, ESCA and firm annual and } \\
\text { CG reports }\end{array}$ \\
\hline & & $\begin{array}{l}\text { Board members' education } \\
\text { (BMED) }\end{array}$ & $\begin{array}{l}\text { The ratio of directors who hold a degree from } \\
\text { developed-country universities to total members } \\
\text { in the board }\end{array}$ & $\begin{array}{l}\text { DFM, ADX, ESCA and firm annual and } \\
\text { CG reports }\end{array}$ \\
\hline & & $\begin{array}{l}\text { Board members' experience } \\
(\mathrm{BMEX})\end{array}$ & $\begin{array}{l}\text { The average number of years of experience of } \\
\text { board members }\end{array}$ & $\begin{array}{l}\text { DFM, ADX, ESCA and firm annual and } \\
\text { CG reports }\end{array}$ \\
\hline \multirow[t]{4}{*}{2} & \multirow{4}{*}{$\begin{array}{l}\text { Audit } \\
\text { committee } \\
\text { characteristics } \\
\text { (ACC) }\end{array}$} & Audit committee size (ACS) & The number of members in the committee & $\begin{array}{l}\text { DFM, ADX, ESCA and firm annual and } \\
\text { CG reports }\end{array}$ \\
\hline & & $\begin{array}{l}\text { Audit committee independent } \\
\text { members (ACIND) }\end{array}$ & $\begin{array}{l}\text { The ratio of independent members to total } \\
\text { members in the committee }\end{array}$ & $\begin{array}{l}\text { DFM, ADX, ESCA and firm annual and } \\
\text { CG reports }\end{array}$ \\
\hline & & $\begin{array}{l}\text { Audit committee meetings } \\
(\mathrm{ACM})\end{array}$ & The number of committee meetings held per year & $\begin{array}{l}\text { DFM, ADX, ESCA and firm annual and } \\
\text { CG reports }\end{array}$ \\
\hline & & $\begin{array}{l}\text { Audit committee members' } \\
\text { education (ACED) }\end{array}$ & $\begin{array}{l}\text { The ratio of number of audit committee members } \\
\text { holding a degree in a financial discipline to total } \\
\text { committee members }\end{array}$ & $\begin{array}{l}\text { DFM, ADX, ESCA and firm annual and } \\
\text { CG reports }\end{array}$ \\
\hline \multirow[t]{2}{*}{3} & \multirow[t]{2}{*}{$\begin{array}{l}\text { Financial } \\
\text { performance }\end{array}$} & Return on Assets (ROA) & (Net income) $\div$ (average total assets) & $\begin{array}{l}\text { DFM, ADX, firm annual reports and } \\
\text { Orbis-Bureau van Dijk and Datastream } \\
\text { databases }\end{array}$ \\
\hline & & Return on Equity (ROE) & (Net income) $\div$ (shareholder's equity) & $\begin{array}{l}\text { DFM, ADX, firm annual reports and } \\
\text { Orbis-Bureau van Dijk and Datastream } \\
\text { databases }\end{array}$ \\
\hline \multirow[t]{3}{*}{4} & \multirow{3}{*}{$\begin{array}{l}\text { Control } \\
\text { variables }\end{array}$} & Firm age (FA) & The number of years since establishment & Firm annual reports, DFM and ADX \\
\hline & & Leverage (LEV) & (Total debt) $\div$ (shareholders' equity) & $\begin{array}{l}\text { Firm annual reports and Orbis-Bureau } \\
\text { van Dijk and Datastream databases }\end{array}$ \\
\hline & & Firm size (FS) & The natural logarithm of total assets & $\begin{array}{l}\text { Firm annual reports and Orbis-Bureau } \\
\text { van Dijk }\end{array}$ \\
\hline
\end{tabular}

\section{Copyright Disclaimer}

Copyright for this article is retained by the author(s), with first publication rights granted to the journal.

This is an open-access article distributed under the terms and conditions of the Creative Commons Attribution license (http://creativecommons.org/licenses/by/4.0/) 